David Watson*

\title{
Failing States, Human (In)Security, and the American World Novel
}

https://doi.org/10.1515/ngs-2019-0005

\begin{abstract}
As a growing number of contemporary American novelists take the world and its socio-cultural and geopolitical complexity as their subject matter, the contemporary novel's form and sense of worldliness are shifting. Twentyfirst century US fiction challenges normative models of the world proposed by theories of cosmopolitan relationality by projecting fragile worlds of strife and trauma, in which violence accompanies geopolitical turbulence. In these novels, discourses around human security-the everyday security needs of vulnerable populations-are increasingly prominent. Accordingly, contemporary US fiction often incorporates within its geopolitical imaginary such issues as human rights, humanitarian interventions, development, and how life is disabled by prejudice, civil war, scarcity, and health or other crises. In this essay, I range across a number of works by contemporary American novelists such as Dave Eggers, Jennifer Egan, Denis Johnson, Dana Spiotta, and Bob Shacochis in which state failures as well as human and geopolitical security concerns impact on the form given to the world by these novelists. In their novels, narratives concerning human security as well as threats to geopolitical stability produce transnational geographies in which global interconnections and circulation intensify feelings of insecurity.
\end{abstract}

Keywords: US fiction, world novel, human security, state failure, humanitarian interventions

In his 2011 periodizing study, Cosmodernism: American Narrative, Late Globalization, and the New Cultural Imaginary, Christian Moraru argues that in the late twentieth and early twenty-first centuries, US fiction is no longer "American" in any coherent fashion. Rather, in contemporary US fiction there develops a new paradigm-“cosmodernism"-wherein literary texts represent globalization's erosion of national boundaries, articulate a strongly relational ethics, and often critique globalization's homogenizing effects on culture. In historicizing what he describes as the emergent American world novel, Moraru

*Corresponding author: David Watson, Uppsala Universitet, Uppsala, Sweden, E-mail: david.watson@engelska.uu.se

Ә Open Access. (C) 2019 Watson, published by De Gruyter. (c) BY This work is licensed under the Creative Commons Attribution 4.0 Public License. 
posits with absolute certainty that 1989, the end of the Cold War, is cosmodernism's “not-so-'arbitrary' birth year" (2011, 315). Yet, if the end of the Cold War inaugurates the history of this literary paradigm, it also appears to ensure the relative autonomy of the American world novel from its immediate post-Cold War context. Moraru suggests that the cosmodern presents an alternative vision of the world and relationality to those of a "geo-political corporate sort": a cosmodern poetics, in his terms, does not lend itself to historical narratives that would frame it fully as the cultural logic of the present moment $(2011,38)$. Indeed, while not quite ahistorical, for him the world novel resists historicization to a degree.

Moraru's periodization threatens to suture together American literary history with post-Cold War neoliberal fantasies about the end of history, and what appeared then to be the emergence of a post-ideological and post-political US global hegemony. Moreover, it raises the question whether the end of the Cold War, and the geopolitical dispensation it instated, should indeed be understood as a precondition for the emergence of contemporary cosmopolitan or world fictions. Before addressing such issues, however, we need more clarity about the geopolitical coordinates of contemporary US fiction. What are the features of the geopolitical imaginary of US fiction? Has it indeed gained a relative degree of autonomy from the geopolitics of the nation-state? In other words, we require greater clarity about the relation, if any, between contemporary US fiction and the discourses around humanitarianism, development, security and military intervention that have typified post-Cold War US international relations.

Events surrounding Haiti's January 2010 earthquake offer a revealing glimpse of the contemporary geopolitical settlement. The earthquake had killed approximately 316,000 people and left a million more homeless. With the earthquake initiating a militarized response, a large Air Force cargo plane flew the initial aid missions to the devastated country. Every day, the plane circled over the rubble-strewn landscape, broadcasting news and a pre-recorded message from Raymond Joseph, Haiti's ambassador to the United States. Don't leave Haiti, Joseph instructed in Haitian Creole, "if you think you will reach the US and all the doors will be wide open to you, that's not at all the case" (McKinley 2010). The secretary of the Department of Homeland Security Janet Napolitano addressed the Haitian people in a televised broadcast, warning them of the dangers of attempting a crossing to the United States. Air Force planes and Coast Guard cutters roamed the waters between Haiti and the United States, while the DHS cleared space for illegal immigrants at the United States detention base at Guantánamo Bay, Cuba (Miller 2014, 198).

Two different geopolitical cultures collided in the United States' response to the earthquake. Hillary Rodham Clinton championed a human-security agenda 
during her tenure as US secretary of state, commenting in a 2011 interview "human security is a concept that I am very committed to enshrining in American foreign policy” (Clinton 2011). A crucial part of the Right to Protect doctrine that has gained international acceptance since 1989, the human-security agenda, as Paul Amar notes, commonly combines victim-focused interventions, frequently of a gender-sensitive nature, with a free-market development program, and is viewed as a substitute for the preemptive and unilateral military-centered interventions advocated by the United States and Britain in the early years of the twenty-first century (Amar 2013, 23-24). Haiti's stricken people acted as the referent for Clinton's victim-oriented human-security agenda, which framed in turn the mobilization of the United States military to assist the shellshocked nation as a "compassionate invasion" (Thompson 2010).

But the shoring up of the borders between Haiti and the United States let loose the specters of a less compassionate security logic. Critical border studies might very well take the wall as its preferential image, as Mezzadra and Neilson (2013, viii) suggest, but in an age dominated from the perspective of the United States by a global war on terrorism as well as the uneven effects of economic globalization and the emergent reality of the climate induced movements of people, borders are less lines of inclusion and exclusion than contracting and expanding zones within which mobility and movement are securitized. Consequently, the US border that needs protecting extends, as Todd Miller notes, to the 'virtual borders of its 'national interest' and the edges of its everexpanding military-surveillance grid" (2014, 197). The response to the 2010 earthquake is informed by this border security logic. Potential refugees were preemptively targeted and dissuaded from attempting a border crossing, even while the logistical means were put into place to manage such an influx. In addition to humanitarian interventions, these measures were used to securitize a Haitian population also implicitly understood as a threat to the American body politic. In this security matrix, discourses of danger and victimhood interact and collide, yoking together a human-security, humanitarian imaginary with security practices and techniques geared toward defending national sovereignty against external threats to its well-being.

The concern of this essay is not to interrogate the humanitarian principles ostensibly informing the US response to the earthquake nor is it to stage an argument concerning the continuation and expansion of a preemptive, militarized approach to security on the part of the United States. Rather, by sketching out the colliding narratives operative in the 2010 response, it seeks to identify a linkage between victim and threat-oriented security agendas that opens up a critical wedge into the geopolitical imaginary of the contemporary American world novel. Specifically, the enframing of post-earthquake Haiti as a space for 
humanitarian intervention and a post-governmental country-a "ward of the ... United States" (Thompson 2017) it needs to police and securitize-invites a meditation on how contemporary US fiction imagines and renders concrete transnational coordinates and geographies, which, as it turns out, are frequently geographies of catastrophe ripe for intervention. In other words, if there is indeed a move towards "world-shaped" and "world-themed" (Walkowitz 2015) fictions among contemporary American novelists, we need a better idea about what geopolitical imaginaries inform the worlds constituted within these texts.

In many ways, what we may term American world novel has replaced the so-called great American novel in the literary imagination, with prestige accruing to worldliness in our contemporary literary culture (Irr 2014). The world novel is supposed to operate on a planetary canvas. In addition to offering, as many have noted, narratives of temporal and geographical scale enlargements, it is frequently thought to be committed to a cosmopolitan ethics. Accordingly, Christian Moraru argues that this type of novel enables a "new togetherness ... a solidarity across political, ethnic, racial, religious and other boundaries," which is grounded in "concepts of concern and duty" (2011, 5). But Bruce Robbins offers the following brutal formula for how the American novel materializes abstract planetary coordinates: "Step one: atrocity in a foreign country. Step two: escape to the USA" $(2011,1099)$. This atrocity and escape narrative suggests to Robbins that the contemporary US fiction falls short of becoming fully worldly.

Caren Irr's synoptic discussion of more than 125 contemporary US novels in her Towards the Geopolitical Novel: U.S. Fiction the Twenty-First Century serves as a useful counterpoint to Robbins' doubts and Moraru's optimism. Tracing the emergence of such micro-genres as the 'Peace Corps' and 'digital migrant' novels, the 'new international novel,' and the 'novel of revolution,' Irr locates the political energy of the contemporary US novel in its engagement with geopolitical issues. It is not only that the world of international relations raises political questions, but also that the world abroad often serves as a laboratory for different forms of liberalism-the political stance with which Irr associates most contemporary authors. Crucially, she finds that normative liberal assumptions concerning cosmopolitanism and humanitarianism are challenged frequently within contemporary US fiction. Just as importantly, while Irr complicates Robbins's claim that the contemporary American novel has not passed the necessary threshold to become worldly, their accounts cohere in illustrating to what degree the world abroad is a world in and of crisis within the American geopolitical imaginary. Robbins calls it atrocity; Irr maps novelistic worlds consisting of victims, revolutions, failing states, and humanitarian catastrophes serving primarily as a testing grounds for the liberal sensibilities of 
the novels' protagonists. "Most authors of the geopolitical novel" she argues, understand contemporary geopolitics as, at the very least, "a moderate crisis" (2014).

Amid all of the variety on display in Irr's and Robbins' engagement with the genre of the world novel, there is one constant: the world is imagined as deeply political, with possibilities for care and solidarity, as well as danger and catastrophes organizing the oscillating relationship between the United States and the rest of the world. We encounter a very similar geopolitical terrain once we turn to contemporary US fiction, with similar tensions visible even among different works by the same author. Few authors have been as committed to raising the global awareness of his readership as Dave Eggers. In a 2013 interview, he comments that

A lot of people like me in Illinois, or Wisconsin, we're well-meaning people, but you would be surprised how 'in the middle of nowhere' we are in terms of our awareness. I didn't have a passport until I was twenty-six. There's a lot of people like us and you've got to be forgiving of people like that. They have good hearts. ... especially with What Is the What and Zeitoun, I'm speaking to those people I grew up with. We're all incredibly nice people who might not be aware of what happened in New Orleans after Katrina, or might not be aware of the human rights crises that Voice of Witness tries to illuminate (2013a, 24).

Though the interview is recent, as far back as his first fictional work, You Shall Know Our Velocity from 2002, Eggers explored the intersection of global travel and philanthropy. The novel depicts an adventurous week in the life of young Americans on a whirlwind world tour during which they attempt to distribute a large amount of money to those in need, even while becoming embroiled in increasingly dangerous circumstances. At the same time, the novel suggests a unique blindness exists amongst traveling young Americans looking to help international communities. Will and Hand undergo a transformation as they come to understand this truth, a transformation the novel seems to impel its readers to follow. After their early donations, Will says, he and Hand

debated briefly whether we were giving people false hope. That now the common belief around these parts, on this countryside, among the rural poor, would be that if one waits by the side of the road long enough, Americans in airtight rental cars and wearing pants that swish will hand out cash $(2002,182)$.

Partially arguing for a conservative form of self-reliance on the part of the rural poor, partially for more sustainable forms of assistance, Eggers complicates even while underwriting the humanitarian efforts of his characters.

While You Shall Know Our Velocity shares in the work of what Irr describes as the testing of liberal sensibilities through encounters with different geopolitical 
spaces, a more recent book by Eggers, What Is the What: The Autobiography of Valentino Achak Deng from 2006, makes a different kind of investment in humanitarian projects. Eggers' nonfiction novel ventriloquizes the life story of Valentino Achak Deng, a 'Lost Boy' of Sudan who is eventually resettled in the United States. In it, Deng is called upon to offer an account of his life story before his eventual resettlement in the United States:

The first step in leaving Kakuma was the writing of our autobiographies. The UNHCR and the United States wanted to know where we had come from, what we had endured. ... We were asked to write about the civil war, about losing our families, about our lives in the camps. Why do you want to leave Kakuma? they asked. Are you afraid to return to Sudan, even if there is peace? ... no deprivation was insignificant $(2006,485)$.

In addition to the brute facts concerning his dislocation and the civil war in Sudan, Deng is invited to depict Sudan as caught in an ongoing, irresolvable crisis preventing it from securing its population now or at any imaginable time in the future. For the United States and the United Nations Refugee Agency, Deng's autobiography underwrites his claim to refugee status and gives evidence that Sudan is a failed state unable to attend to its population. But it could also be read as a preliminary draft of What Is the What, a novel in which no deprivation is insignificant. The autobiography leads both to Deng's resettlement and to Eggers' rejoinder and elaboration, which expands Deng's autobiography into a series of comparisons between Deng's life in the Sudan and the United States.

One way to read this passage from What Is the What is to view Deng as enabling and producing a particular scene of recognition. The administrative context within which he writes his life story, and its content-that which he has endured-conspire to identify him as a partially self-validated victim and witness to a traumatic history. The autobiographical intimacy of What Is the What, a product of Eggers' unobtrusive ventriloquizing of Deng, calls upon the reader in turn to act as a second-order witness to what Deng has endured, and thereby to situate him within a long traumatic history that the text makes legible for us. This type of recognition is certainly productive of the transnational solidarities many associate with the world novel genre, and inviting of a geopolitics of care and humanitarian assistance. Unsurprisingly then, the McSweeney's (2017) webpage for the book suggests

Deng, with Eggers, clearly intended the telling of his story to be a prompt to action. All proceeds from the novel are going to The Valentino Achak Deng Foundation, dedicated to helping Sudanese refugees in America, rebuilding villages in southern Sudan and funding humanitarian aid in Darfur. 
Arguably, if we were to scale-up from Deng and his experiences a different story would come into view. This is necessarily difficult given Deng's centrality to the narrative, but in doing so a different geopolitical picture appears in view. Within this frame, Deng's plight is directly attributable to the failures and failing of the Sudan, and he is but one example from a population trapped within ongoing violence. The global condition rendered legible for Egger's readers here is one in which the globe is scarred by failing states in which acts of intolerable violence are common currency, and, following Robbins, flight to the United States is the best response. This world is closer in kind to the one imagined in Eggers' shortshort story "When They Learned to Yelp," initially published in the Guardian in August, 2004. Writing with generation-defining intent, Eggers suggests in the story that his life and of others of his generation are shaped by the experience of mediated images of violence, ranging from natural disasters to mass killings to the attacks on the World Trade Center in New York. The effect is intimate and embodied, it produces a convulsive "yelp"-a combination of "the shriek, the whine, the moan" $(2005,208)$-with which others in the rest of the world are familiar, unlike his generation. The story culminates with the appearance of a grainy film online. While not directly identified as such, the online film might very well be the five-and-a-half-minute footage released in May 2004 of Abu Musab al-Zarqawi decapitating the abducted Nick Berg, dressed in an orange jumpsuit, in retaliation for the Abu Ghraib prisoner abuses involving the United States armed forces and Iraq prisoners. "When They Learned to Yelp" dispenses with political analysis to focus on the distressing affects unleashed by the war. These affects are shared by the nation: the "yelp" synchronizes distant events and ordinary, everyday lives; rolling across the nation, it unites a generation in the experience of trauma, and realigns this generation's relationship to the rest of the world, implicitly associating distant geographies with forms of violence and terror intruding into the relative safety of the United States. Detachment is perhaps the logical strategy to adopt within such a situation. Accordingly, in his recent The Circle (2013b), a novel about data mining and global surveillance, Eggers depicts how dataveillance practices allows the main character to "save lives ... halfway across the globe” thanks to a twitter-like intervention into the kidnapping of witness to ritual rapes by "a paramilitary group in Guatemala, some resurrection of the terrorizing forces of the 80s" (2013b, 242). Mediated violence begets a virtual response, which is at once tacitly enabling even while it reinforces the distance between the responder and the violence itself.

What is of interest here is Eggers' investment in a fluctuating geopolitical imaginary within which the rest of the world offers the opportunity for humanitarian interventions even while confronting an American audience with scenes of intolerable violence, and appears as a looming crisis. The scene in What Is the 
What where Deng is compelled to write his autobiography suggests one reason for this particular mode of worlding. Deng's autobiography is written within a context produced by the coordinated humanitarian action of agencies of the United States and the United Nations. It is expected to address questions about intra-state conflict, the failure of a state to secure its population, and, most of all, how he would position his own deprivations at the center of this narrativequestions figuring prominently within human security and developmental agendas. With a history stretching back to Boutros Boutros-Ghali's influential "An Agenda for Peace" of 1994, the discourse on human security too places the victim at the center of its enquiries (1995, 39-72). As the United Nations Development Program puts it, it emerged as a means of addressing "the legitimate concerns of ordinary people who sought security in their daily lives:"

The concept of security has for too long been interpreted narrowly: as security of territory from external aggression, or as protection of national interests in foreign policy or as global security from the threat of a nuclear holocaust. It has been related more to nationstates than to people. ... Forgotten were the legitimate concerns of ordinary people who sought security in their daily lives. For many of them, security symbolized protection from the threat of disease, hunger, unemployment, crime, social conflict, political repression and environmental hazards. With the dark shadows of the cold war receding, one can now see that many conflicts are within nations rather than between nations $(1994,22)$.

A post-Cold War phenomenon, human security emerged as a substitute for realist accounts of security primarily concerned with defending the sovereign borders of the state. It proceeds from the understanding that internal conflicts have largely replaced inter-state wars in a post-containment world. As Mary Kaldor puts it, human security seeks to address the problem that contemporary wars are "usually fought not for reasons of state or ideology, but for identity. Battle is rare and most violence is directed against civilians" (Kaldor 2007). Taking up the challenge of addressing the plight of victims of internal conflicts, human security discourse incorporates within a security framework issues such as human rights, development, illicit economies, epidemics, and trans-border criminality. It gives serious attention to how a given population is affected by a lack of infrastructure, poverty, resource scarcity, climate shifts, civil war, and various state failures. To put this otherwise, the human-security agenda takes as its referent object what Brad Evans calls "underdeveloped life" (2013, 44), life disabled by prejudice, civil war, scarcity, and health or other crises. This form of life is targeted via humanitarian interventions, attempts at sustainable development, and increasingly, imperatives to become resilient-the neoliberal demand to adapt to endemic threats and dangers. Frequently targeting specific ethnic or cultural groups within a state, the types of interventions imagined by human 
security include development assistance, the introduction of free market policies, cultural rescue missions, victim-focused projects, and counter-insurgency missions-the constitutive elements of what Didier Fassin and Richard Rechtman (2009) describe as a global empire of trauma. As recently as 2009, the discourse of human security was reaffirmed as the framework within which global interventions need to occur by Hillary Rodham Clinton, who was widely acclaimed as the human security champion, Bernard Kouchner, French foreign minister and co-founder of Médecins Sans Frontières, and Navanethem Pillay, the United Nations high commissioner of human rights. As Paul Amar (2013) has described in detail, during the last decade various permutations of human security discourse have appeared in the Global South as well, as various indigenous populations and minority groups adopt its language to describe their own efforts at securing a safer world.

It appears that the discourse on human security accomplishes three things: (1) it widens the security agenda to include components of humanitarian and developmental discourses, (2) isolates a form of population or life-underdeveloped life-that will henceforth serve as its target object, and (3) identifies types of intervention superficially distinct from say pre-emptive wars and surveillance to address conditions putting a particular population at risk. It is unabashedly biopolitical in Foucault's sense, seeking to make live the life of the individual through a "complex set of strategies initiated at the level of populations" (De Larringa and Doucet 2008, 528), with the health and welfare of populations constituting its frame of reference. Human security is concerned with a specific aggregate of a population that has ceded responsibility for their security to the state or a different organization. Taken as such, human security is a form of biopower, which Michael Dillon and Julian Reid, following Foucault, explain as a "positive and productive form of power that conceived the task of government in terms of the management of populations by systematically assaying their needs, compositions, properties and dynamics in order to promote their welfare" (Dillon and Reid 2001, 49). More simply, it names then the art of securing the physiological necessities for human life to persist within a given milieu.

Simultaneously, human security initiates a post-Cold War remapping of the globe. As Mark Duffield notes, it divides "humankind against itself in the generic form of developed and underdeveloped species-life" (2007), and compounds this division by separating out a transnationally articulated sets of states and organizations responsible for human security from nation-states understood as fragile or failed since they have relinquished control over and responsibility for the security of their populations. This is a crucial point: though seemingly grounded in a progressive, cosmopolitan notion of development and humanitarianism, human security retrieves the nation-state as a meaningful geopolitical category. 
It does so by distinguishing between what Mark Duffield (2007) terms effective and ineffective states, with the latter serving as the field within which human security interventions take place and towards which development strategies are geared. Human security thus enters into an alliance with ideas of state failure, with the void of failed states and the vulnerable, precarious environments of fragile states functioning within the contemporary geopolitical imaginary as sites for counter insurgency missions, and moreover, locations of potential dangers, whether refugee crises, terrorist formations or trans-border criminality. One effect of human security is then to make nation-states responsible for human security crises, even while allocating these states only a contingent form of sovereignty, since it necessitates international interventions geared towards rescuing specific sections of a population from failing states. A particular kind of sorting effect can then be attributed to human security discourses. Human security arranges and opposes developed and underdeveloped species life, as well as differentiating between transnationally articulated humanitarian interventions and power blocks or failing nation-states that have had their sovereignty eroded.

Readers of contemporary American fiction would not be surprised by this demarcation between underdeveloped populations at risk, and, as Randy Martin (2007) would describe them, those largely in the Global North who can assume and manage risks and contingencies themselves. It has often been the task of the American novel straining after worldliness to illuminate geographies very similar to this post-Cold War remapping of the world. Robert Rosenberg imagines a world of refugees in his Peace Corps novel This Is Not Civilization (2005), which yokes together Kyrgyzstan, Turkey, and, interestingly, a Native American reservation. The people in these spaces, the former Peace Corps volunteer tells us, have left "war-ravaged nations. They fled distant mountain villages and the rusting ports of four different seas. They arrived with oversized bundles, crowded in burnt-out apartment buildings, collected in neighborhoods of shoddy cement structures and crouching cardboard houses" (2005, 286). In this catastrophic vision, crises multiply with war refugees producing a crisis in which poverty and resource scarcity are the paramount problems. A similar map is drawn for Bolivia in Peter Mountford's A Young Man's Guide to Late Capitalism (2011), which takes place during the 2005 presidential elections in Bolivia, where Mountford himself worked, and details how Gabriel, an equities analyst, attempts to generate profit from the political transformation and turmoil in the country. Linking Bolivia and Rwanda, the narrator notes that in such places "If civil war doesn't get you, famine, cholera, or a pink-toe hangnail that gets infected and then goes haywire will ... there could be no escaping death's proximity" (2011, 136). In Mountford's novel, this distress is linked directly to 
violence. People "all over the world are blowing themselves up these days" (168), Gabriel notes, connecting for the reader the scenes of poverty in the novel to geopolitical turbulence.

These demarcations between secure and insecure spaces also appear in discrete moments in texts less concerned with inhabiting divergent geopolitical spaces as such, and more with viewing the world abroad from the relative security of the United States. Watching reports concerning the taking of hostages at a school in Chechnya, the protagonist of Dana Spiotta's Stone Arabia (2013) wonders whether, perhaps, the parents of the children were inured to the horrific events- "they were used to it, in these chaotic foreign countries. They were used to violence and terror and collateral death. Child death" $(2013,215)$. In one of the many proleptic sequences in Jennifer Egan's multi-stranded novel $A$ Visit from the Goon Squad (2010), she offers the following account of different life courses as these are inscribed in human subjects and objects:

Thirty-five years from now, in 2008, the warrior will be caught in the tribal violence between the Kikuyu and the Luo and will die in a fire. One of his grandchildren, a boy named Joe, will inherit his lalema: the iron-hunting dagger now hanging at his side. Joe will go to college at Columbia and study engineering, becoming an expert in visual robotic technology that detects the slightest hint of irregular movement (the legacy of a childhood spent scanning the grass for lions). He will marry an American named Lulu and remain in New York, where he'll invent a scanning device that becomes standard issue for crowd security. He and Lulu will buy a loft in Tribeca, where his grandfather's hunting dagger will be displayed inside a cube of Plexiglass (2010, 61-62). ${ }^{1}$

The reference to Joe's security scanner that identifies threats via the data points of a crowd is hardly necessary to make sense of the contrast between the preemptively terminated life of the grandfather, subsequently memorialized like a still life captured in plexiglass, and Joe and Lulu's open-ended life in New York, or of the passage's contrast of insecure and secure frames for life. Or of how the novel itself functions as a biopolitical scanner, producing information about risks and potential for survival, even while drawing our attention to the development of various security technologies.

Denis Johnson's The Laughing Monsters from 2014 is steeped in the type of landscape within which human security crises emerge. Shaped by Johnson's travels in Liberia during its civil war in the 1990s, a war that saw 200000 killed

1 For more on Egan's proleptic narratives see Bruce Robbins' "Many Years Later: Prolepsis in Deep Time.” Robbins suggests that Egan's use of prolepses might very well have something to do with the broader question concerning with what community the reader can identify in the novel (2012, 200-201). If so, the novel's distinction between vulnerable modes of life and secure communities impacts directly on its narrative mode. 
and a million refugees displaced, The Laughing Monsters generalizes the "happy horror" (2001) Johnson thought dominated in Liberia and brings it to bear on its depiction of Sierra Leone and Uganda. In the background of the novel lurks the US's increasing presence in the African continent, where the US Africa Command (AFRICOM) has made inroads into 49 of the 54 countries on the continent. $^{2}$ The Laughing Monsters pulls together three characters in its main narrative: Nair, a Danish-American working for NATO intelligence, his friend Michael Adriko, a lethal, merry Ugandan, and Davidia, the daughter of the camp commander of the United States 10th Special Forces Group stationed in Africa, from which Michael is AWOL. Nair is ostensibly checking up on Michael, who claims to have gained access to enriched uranium, but he is really in Africa because Michael has summoned him to attend his wedding to Davidia in his childhood village. A different narrative within the novel, however, circles around the attempts of the two men to get rich in an Africa described as a "land of chaos, despair" whose inhabitants are metonymically figured as "a multitude of shadows and muddy rags trudging God knows where, hunched forward over their empty bellies" (2014, 28, 4). Predictably this image of life disabled by poverty and hungers blurs in the novel into a representation of Africa in which nation-states are endowed with a weak form of sovereignty at best. Michael suggests that here "we make ourselves unreachable. A man can choose a valley, one with narrow entrances-defensible entries-and claim it as his nation, like Rhodes in Rhodesia” (2014, 28). In fact, in The Laughing Monsters an Africa made-up out of fragile states fuels imperial fantasies, fantasies emboldened by the expansion of the global defence and security industry, what Nadir calls "an expanded version of the old Great Game” (2014, 122).

As the novel develops, however, a different narrative emerges around Michael. If Africa is indeed the anarchic space Nadir presents it as, we discover that Michael has been shaped by its violent, chaotic history. In one version of his history, it is suggested that he belongs to the Kakwa ethnic group like the Ugandan dictator Idi Amin. After Amin was deposed in 1979, many of the Kakwa were killed in retribution. As a direct result, a criminal gang kidnapped Michael, who survived on the streets as a "harlot boy" $(2014,48)$ before entering into military service. When Michael returns to his people he finds that, as an aid worker puts it, the "people are crazy, the water is poison, everybody's dying" (2014, 192). For the aid worker, a Seventh-Day Adventist about to escape the region, this is what she terms a "spiritual travesty" $(2014,193)$, but it seems to me the novel allows for a less metaphysical account of what is taking place.

2 For an account of the US's pivot to Africa see Nick Turse's Tomorrow's Battlefield: US Proxy Wars and Secret Ops in Africa. 
Obviously, civil war, ethnic violence, and resource scarcity are paradigmatic of the crises associated with failing states, and by making Uganda the scene of a humanitarian intervention, the novel implicitly associates it with the humansecurity agenda. However, Michael's double life as a victim of ethnic strife and a soldier with a loose association with the United States armed forces, who is about to marry the daughter of his commander, deserves further attention. He mediates in the novel between two competing visions of geopolitical geographies: multicultural spaces open to difference and regions of ethnoreligious strife. Neda Atanasoski suggests that in the post-Cold War reorganization of the globe in the 1990s two narratives were deployed: "the racial progress narrative of multiculturalism, on the one hand, and the cyclical violence narrative framing ethnoreligious conflicts" (2013) on the other. With the former taken as an intrinsic feature of the developed world, and the latter of ineffective governments, this opposition also served to legitimize violent and humanitarian interventions imagined as being geared towards the liberation of peoples from ethnic and religious conflicts. Consequently, the rhetoric of multiculturalism was operationalized with a global human and military security imaginary. Michael's life story articulates together these opposing narratives, within which he occupies multiple identity positions-victim, redemptive multicultural soldier, and, most of all, the "laughing monster" confirming for the reader the "happy horror" of Africa.

But if life abroad is characterized by its insecurity in many contemporary American novels, then it is also true, as Johnson's fleeing Seventh-Day Adventists remind us, that it provides a space for what Caren Irr would describe as liberal experiments in humanitarianism. This can only take place in the contemporary American novel against a backdrop of weak or failing states where life becomes dangerous and in need of intervention. Denis Johnson's writing again serves as a useful example. His Tree of Smoke (2007) contrasts its narrative of plots and counterplots during the Vietnam War to a subdued counter-narrative involving the actions of Kathy, a Seventh-Day Adventist and aid worker, who concludes the novel with the repetition of the half-prayer, halfinjunction, "all will be saved" $(2007,814)$. This injunction is put to the test in what Irr calls the genre of the Peace Corps novel. Tony D'Souza's Whiteman (2008) one instance of this genre, draws together depictions of resource scarcity, local unrest, a black market in food aid, and HIV/Aids in Côte d'Ivoire with a story, based on D'Souza's own experiences, of how a volunteer working for a fictional aid organization, Portable Water International, discovers the limits of American-style liberalism, and his own capacity for effecting change. ${ }^{3}$ Former

3 For an in-depth discussion of this novel, see Irr's Towards the Geopolitical Novel. 
Peace Corps volunteer, Norman Rush's Botswana novel, Mortals (2004), surveys a post-Cold War Botswana where, as the narrator reflects, the government fails to work, and the "development process itself ... never seemed to get finished" (2004). Botswana emerges first and foremost in the novel as a space where the developmental process breaks down, grinding to a halt due to internal resistance:

Here was sanitation and technology and the buildings in which people were hanging around in order to get paychecks. All this had been provided to Africans who were only one generation away from herding cattle and chasing witches and going broke raising mealie on patches the size of tennis courts. The question of what was ultimately going to be done with all this by the Batswana was always just under the surface, and the question was kept hot by the steady fixation the Batswana seemed to have on beating back the white tide (2004).

In addition to its disillusioned account of humanitarian and developmental projects in Botswana, the expansive novel is filled with stories such as that of how the novel's main character Ray, a CIA agent teaching English at an Anglican school, is captured and tortured by South African Boer mercenaries. As Ray's background might suggest, generically speaking, novels such as Mortals are as much indebted to the genre of the thriller, as they are to the long history of governmental and non-governmental interventions in complex emergencies destabilizing populations in fragile states. These novels seek to combine an imaginative exploration of the covert sector with accounts of emergent and complex humanitarian crises, as if these two types of narrative are defining of the contemporary geopolitical climate. Complex humanitarian emergencies, resulting as much from poverty and resource scarcity as political or other forms of organized violence, generate a potential for violence in these texts that threatens to overturn the humanitarian plots of the novels into narratives of threat and atrocity.

The fragile states at the heart of the novels under discussion here are depicted as products of the failure of attempts at reconciling demands for progress, order, and the security of the population. Lacking various capacities and political will, these states are unable to secure their populations or attend to the needs of aid and humanitarian projects. By extension, simply by existing they are figured as threatening the global order. In an interconnected and complex world, the only kind of world in which the genre of the world novel is possible, the fragile state represents the threat of ungoverned spaces. They exist on a global borderland resistant to the discourse of human security and development, which, within a contemporary geopolitical imaginary, also suggests that the fragile state and its ungoverned spaces are spaces for the 
emergence of unpredictable forms of criminal activity and terror. ${ }^{4}$ Human security interventions and militarized responses go hand in hand in the securitization and militarization of these unruly spaces. So, in the US Quadrennial Defense Review Report of 2010, it is explained that

The wars we are fighting today and assessments of the future security environment together demand that the United States retain and enhance a whole-of-government capability to succeed in large-scale counterinsurgency (COIN), stability, and counterterrorism (CT) operations in environments ranging from densely populated urban areas and megacities, to remote mountains, deserts, jungles, and littoral regions. ... Accordingly, the US Armed Forces will continue to require capabilities to create a secure environment in fragile states in support of local authorities and, if necessary, to support civil authorities in providing essential government services, restoring infrastructure, and supplying humanitarian relief $(2010,20)$.

The danger driving this turn towards counterinsurgency and human security concerns is that low-intensity, generalized political instability will threaten radically interconnected ways of life. The American homeland and fragile states are interconnected through a security logic that makes failing states an external border to the United States that it needs to police and shore up in the name of its own security. Part of this is driven by a desire to curb and regulate the flow of asylum seekers and refugees, thereby securing global circulation. But the discourse of human security and this way of imagining failing states also enable the incorporation of ungoverned spaces and underdeveloped life into the security matrix of the United States, where they play a double role as the object of both humanitarian interventions and threat assessments. Arguably, the fundamental paradox of the contemporary geopolitical dispensation, in which human security discourse looms large, is that it describes both a biopolitical project geared towards making life live, as well as the securitization of this life a potential threat, with the differences between these two projects growing so indistinct that they often meet and connect within the same segment of the population, the same person.

Perhaps no novel in recent memory has captured this complex dynamic as well as Bob Shacochis' The Woman Who Lost Her Soul, a finalist for 2014's Pulitzer Prize for fiction. Shacochis is a former Peace Corps volunteer, whose previous novel, the National Book Award nominated Swimming in the Volcano, was based in part on his experiences with the Corps in the Caribbean. Ostensibly dealing with an attempted coup in St. Catherine, this 1990s novel is filled with ruminations on how the US government worries that the island will succumb to

4 See, for instance, Brad Evans' Liberal Terror (2013, 45-52). 
the "Cuban disease" of communism, and deals in part with the story of the American Wilson, who works in the "foreign aid biz" and who will return to the United States to ponder the "mystery of his own altruism" (1993, 483, 109, 101). The Woman Who Lost Her Soul is the long awaited second installment in the trilogy that began with Swimming in the Volcano (1993). Like the previous novel, it is concerned with the impact of American foreign policy on smaller nations in crisis, and investigates the "needling American fetish for altruism" (1993, 334). It is also a self-consciously geopolitical world novel, capturing both Shacochis's concern with contemporary manifestations of American imperialism, and his belief that the contemporary novel should offer the "big picture" $(1995,11)$ it should teach us to "recognize ourselves as travelling companions in the mutuality of our tenure on earth" (1995, 121).

However, The Woman Who Lost Her Soul draws less upon his experiences in the Peace Corps than Swimming in the Volcano did. Instead, it is sourced extensively in his experiences as a war correspondent in Haiti in 1994, where he covered the uprising against Jean-Bertrand Aristide, the nation's first democratically elected president, and the subsequent intervention by US Army Special Forces, with whom Shacochis travelled for a year. In his journalistic account of the invasion in The Immaculate Invasion (2010) Shacochis notes that the United States imagined Haiti not "even a sovereign nation," but as a "boneyard carnival" where governments "went up and down like tin ducks in a shooting gallery," while the Special Forces were, at least initially, thought of as the "Peace Corps with guns," and "altruist in uniform ... the military's easy-toapply contribution to the quixotic but simultaneously ambiguous crusade for global democracy, the mythic Arcadia of free-market capitalism."

The Woman Who Lost Her Soul begins in the Haiti depicted in The Immaculate Invasion before developing into a network narrative in the sense given to this term by Caroline Levine-it connects political, economic and social networks even while aggregating in its narrative different points in space and time (2015, 112-131). From Haiti in the 1990s, the reader travels with the narrative in space and time to Croatia in the 1940s, Istanbul in the 1980s, Sarajevo and Nairobi in the 1990, as well as to America and back to Haiti. Inspired, so Shacochis (2013a) claims, by Thomas Pynchon's Gravity's Rainbow and Tom Clancy's thrillers, it is Shacochis' attempt at a world novel. Its byzantine plot involves, amongst other things, the unfolding relationship between a father and daughter. The daughter, sometimes called Dorothy Chambers, other times Jackie or Alice, is drawn into a thrilleresque world of counter-intelligence involving terrorism and drug wars by her father after a disastrous relationship with a young Muslim in Istanbul. The father, undersecretary of state, Steven Chambers is also Stepjan Kovacevic. During the German occupation of Croatia in World 
War II, he saw his father beheaded by one of Tito's Muslim partisans, an event that inducts him from early on in an ethnoreligious conflict he pursues up into the present, under the guise of working for the American government. The novel begins with an encounter in Haiti between the daughter and Thomas Harrington, a human rights lawyer investigating claims of human rights abuses and genocide in the country. Towards the end of the novel, the daughter enters into a relationship with a Special Forces soldier, Eville Burnett, who was stationed in Haiti at the beginning of the novel and to where returns later on, and who has also carried out missions in the Balkans for Steven Chambers. During the course of the novel narrative, the Second World War morphs into the Cold War and edges into the contemporary war on terror. At the same time, the cascading narrative of the novel pulls the reader from depictions of war zones into the world of the covert sector, where conspiracies, intricate networks, and the secret workings of the state and its military promise to explain or at least illuminate the historical events the novel portrays. In this sense, Shacochis' novel is also a novel of the covert sphere, the "discursive forms and cultural institutions through which the public can 'discuss' or, more exactly, fantasize the clandestine dimensions of the state" (Melley 2014).

In the long opening section of the novel, the reader is introduced to a Haiti described notably as "postfunctional, a free-range concentration camp" (2013b, 22) unable to save itself- "the democracy you give Haiti is killing us" (2013b, 23) a Haitian remarks to Harrington, suggesting Haiti is less a failed state than one excluded per se from a developmental narrative. The novel differentiates between the Haitian population and the people circulating through Haiti in ways resembling the divisions drawn by human security discourses: American soldiers take over the task of governance and providing security, hammering roofs back on schools, digging wells, and feeding children, while international organizations, or rather their representatives, investigate human rights abuses, and UN troops provide a measure of stability. Haitians are figured as victims and violent criminals. Towards the end of the novel, Burnett while helping a Haitian woman and her son imagines that the woman, beyond all political or ethical allegiances, views life purely in terms of survival. For her "being alive and staying alive was a reflexive force that only death denied" (2013b, 555) and to satisfy this force she would submit to any benefactor. This overpowering desire for survival emerges in the novel as a counterpoint to the notions of victimhood underwriting the discourses on human security and development. This desire allows life to be framed purely in terms of its survival or non-survival, with the survival imperative trumping any commitment, political allegiance, or relationship. In fact, in the face of suffering in Haiti, Thomas Harrington suggests that humanitarian interventions are nothing more than "self-deceptions best 
described as crimes of enlightenment," the biggest of these being an allegiance to notions of human rights, what the novel calls "the toilet that powerful men shit in" (2013b, 127). In a familiar move, Haiti tests and destroys liberal assumptions about humanitarianism and rights, including assumptions about the a priori validity and relevance of rights claims, and the forms of recognition elicited by claims to victimhood.

In Shacochis' novel Haiti appears to be a laboratory for interventionism and a catastrophic, dangerous geography. Interestingly, the novel's cascading, temporal shifts positions it as one example of state failure that, in the novel, stretches back to Croatia in the 1940s. Indeed, the most abject scenes in the novel appear in the section of the text dedicated to World War II. In essence, the novel suggests, the countries of Southeast Europe are "lawless dead zones ... where generals begat warlords and warlords begat gangsters" (2013b, 219). Within the world literary frame of the novel, this incessant repetition of state failure indicates that "the planet was chock full of expendable people, overflowing with targets, and genocide an organic event, as common as wheat harvest" (2013b, 498). The long, planetary history suggested by the novel maps comfortably onto a geopolitical imaginary geared towards fragile states and victims, or underdeveloped life. More than that, it is a planetary history in which intra-state warfare and ethnoreligious religious conflict take center stage. The novel's turn towards spaces such as Croatia may very well be explained by what Neda Atanasoski describes as the "hypervisibility of the Balkans as a site of ethnoreligious strife in the US imaginary" (2013) which rendered it at once a space for intervention and a preferential example of the conditions resulting in state failure. In this fashion, the World War II narrative in the novel looks forward to the internal strife of the Haitian portion of the narrative, and beyond that, to the ethnic and religious tensions Steven Chambers introduces into the novel's representation of the contemporary war on terror.

The Woman Who Lost Her Soul also invites the reader in an anachronistic reference to post-9/11 security discourse to "connect dots that don't exist" (Shacochis 2013b, 90). Combing traits of the thriller and the world novel, The Woman Who Lost Her Soul asks of the reader to connect events in Haiti in 1994 to geographical shifts in the illegal drugs trade, in which Mexico replaces Central America as the major source of illegal substances moving the United States, as well as to the illegal entry of figures from Afghanistan and Syria into the United States. Ethnic strife in Croatia during World War II is connected to ethnic cleansings and war in Southeast Europe in the 1990s, and, via the figure of Steven Chambers, to US involvement in Afghanistan and then to the ideologies informing the US war on terror. The 1980 coup in Turkey is connected furthermore to the rise of terrorist fundamentalist groups, and in a final twist, 
Chambers' daughter is killed in the 1998 bombing of the United States Embassy in Nairobi, the same bombing that brought al-Qaeda first to the attention of the United States public. In the sometimes-hallucinatory logic of the novel, ethnic violence in World War II blurs into Cold War politics, into the wars of the 1990s and finally looks forward to the war on terror of the twenty-first century. The planetary landscape given form to in the novel is a complex one, in which intricate connections and emergencies can at any moment lead to the emergence of unforeseen catastrophes and geopolitical turmoil. Failing states and insecure populations drive the engine of this history, with the novel articulating on an expanded scale the link between fragile states and global insecurity saturating contemporary governmental and security policies.

If a world novel such as The Woman Who Lost Her Soul can be said to accomplish the work of making legible geopolitical conditions then it produces, or rather reproduces, a geopolitical optics via which fragile states and humanitarian, biopolitical interventions are securitized, reformulated as signs of impending threat or unknown risks. Human security and threats to geopolitical stability form the warp and woof of this mode of worlding in contemporary US fiction, a worlding that produces not a cosmopolitanism of care or solidarity, but a cosmopolitanism within which global interconnections and circulations are first and foremost security risks. That is as much to say, novels of this type do not so much depict the failure of American style liberalism, or present human security discourses as a façade covering up the biopolitical and geopolitical imperatives of imperialism. Rather they identify an anomie at the heart of humanitarianism and human security, a zone of indistinction in which it becomes impossible to separate out discourses concerning trauma, victimhood, and human security, and others pertaining to failing, rogue states, dangerous forms of life, what Laura Wilcox calls "inhumanity" $(2016,145)$, and intolerable forms of violence that need to be securitized and contained before they engulf other geopolitical spaces.

In addressing how different processes of worlding play out in literary works, Pheng Cheah argues that the imaginative and critical work going into the production of a world should be "responsible and responsive to the need to remake the world as a hospitable place, that is, a place that is open to the emergence of peoples that globalization deprives of world" $(2014,326)$. Let me pivot Cheah's imperative towards contemporary US fiction with worldly ambitions, and in doing so turn it into a question: are the worlds of this fiction indeed hospitable? Geopolitical novels such as Shacochis' that are attuned to the borderlands of the globe may very well fall short of imagining hospitable worlds. Rather than offering an aesthetic or even ethical transvaluation of contemporary geopolitics, they bear witness to its closures, and to its securitization of 
narratives of hospitality, circulation, and humanitarian efforts. This failure of their collective imagination may very well be attributable to authors such as Shacochis's experiences with humanitarian efforts, Peace Corps volunteer work, and journalistic work. More pertinently, we may suggest that contemporary US fiction achieves a degree of worldliness by stretching to accommodate and include geopolitically charged elements of the global scene. Rather than turning away from history and geopolitics at the end of the Cold War, this fiction demands to be read in relation to the geopolitical narratives with which it is imbricated.

\section{References}

Amar, Paul. 2013. The Security Archipelago: Human-Security States, Sexuality Politics, and the End of Neoliberalism. Durham, NC: Duke University Press.

Atanasoski, Neda. 2013. Humanitarian Violence: The U.S. Deployment of Diversity. Minneapolis, MN: University of Minnesota. Kindle edition.

Boutros-Ghali, Boutros. 1995. "An Agenda for Peace: Preventive Diplomacy, Peacemaking and Peacekeeping." In An Agenda for Peace: 1995, In: Department of Public Information, United Nations. 39-72. New York: United Nations.

Cheah, Pheng. 2014. "World against Globe: Towards a Normative Conception of World Literature." New Literary History 45 (3): 303-29.

Clinton, Hillary. 2011. "Our Interview with Secretary of State Hillary Clinton." Interview by Gini Reticker. PBS, October 25. http://www.pbs.org/wnet/women-war-and-peace/features/ourinterview-with-secretary-of-state-hillary-clinton/.

D’Souza, Tony. 2008. Whiteman. New York: Harcourt.

De Larringa, Miguel, and Marc Doucet. 2008. "Sovereign Power and the Bio-Politics of Human Security." Security Dialogue 39 (5): 517-37.

Dillon, Michael, and Julian Reid. 2001. "Global Liberal Governance: Biopolitics, Security and War." Millennium: Journal of International Studies 30 (1): 41-66.

Duffield, Mark. 2007. Development, Security and Unending War: Governing the World of Peoples. Cambridge: Polity Press. Kindle edition.

Egan, Jennifer. 2010. A Visit from the Goon Squad. New York: Anchor Books.

Eggers, Dave. 2002. You Shall Know Our Velocity. San Francisco: McSweeney’s Books.

Eggers, Dave. 2005. "When They Learned to Yelp." In How We Are Hungry: Short Stories, In: Dave Eggers (ed.). 207-11. London: Penguin Books.

Eggers, Dave. 2006. What Is the What: The Autobiography of Valentino Achak Deng. New York: Vintage Books.

Eggers, Dave. 2013a. "Beyond the Lattice: The Dave Eggers Interview." Interview by D'Arcy Doran. Huck, April/May: 20-28.

Eggers, Dave. 2013b. The Circle. San. Francisco, CA: McSweeney's Books.

Evans, Brad. 2013. Liberal Terror. Cambridge: Polity Press.

Fassin, Didier, and Richard Rechtman. 2009. The Empire of Trauma: An Inquiry into the Condition of Victimhood. Princeton: Princeton University Press. 
Irr, Caren. 2014. Toward the Geopolitical Novel: U.S. Fiction in the Twenty-First Century. New York: Columbia University Press. Kindle Edition.

Johnson, Denis. 2001. Seek: Reports from the Edges of America and Beyond. New York: HarperCollins. Kindle edition.

Johnson, Denis. 2007. Tree of Smoke. London: Picador.

Johnson, Denis. 2014. The Laughing Monsters: A Novel. New York: Farrar, Strauss and Giroux. Kaldor, Mary. 2007. "New Wars and Human Security." Interview by Alan Johnson Democratiya 11, Winter. https://www.dissentmagazine.org/democratiya_article/new-wars-and-humansecurity-an-interview-with-mary-kaldor.

Levine, Caroline. 2015. Forms: Whole. Rhythm, Hierarchy, Network. Princeton: Princeton University Press.

Martin, Randy. 2007. An Empire of Indifference: American War and the Financial Logic of Risk Management. Durham, NC: Duke University Press. Kindle edition.

McKinley Jr, James C. 2010. "Homeless Haitians Told Not to Flee to US.” New York Times, January 18. http://www.nytimes.com/2010/01/19/us/19refugee.html?_r=0.

McSweeney's.net. 2017. "About What Is the What." http://www.mcsweeneys.net/pages/aboutwhat-is-the-what.

Melley, Timothy. 2014. The Covert Sphere: Secrecy, Fiction, and the National Security State. Ithaca, NY: Cornell University Press. Kindle edition.

Mezzadra, Sandro, and Brett Neilson. 2013. Border as Method, Or, the Multiplication of Labour. Durham, NC: Duke University Press.

Miller, Todd. 2014. Border Patrol Nation: Dispatches from the Front Lines of Homeland Security. San Francisco, CA: City Light Books.

Moraru, Christian. 2011. Cosmodernism: American Narrative, Late Globalization, and the New Cultural Imaginary. Ann Arbor, MI: University of Michigan Press.

Mountford, Peter. 2011. A Young Man's Guide to Late Capitalism. New York: Mariner.

Robbins, Bruce. 2011. "The Worlding of the American Novel." In The Cambridge History of the American Novel, edited by Leonard Cassuto, 1096-106. New York: Cambridge University Press.

Robbins, Bruce. 2012. “Many Years Later: Prolepsis in Deep Time.” Henry James Review 33 (3): 191-204.

Rosenberg, Robert. 2005. This Is Not Civilization. New York: Mariner.

Rush, Norman. 2004. Mortals. New York: Vintage. Kindle edition.

Shacochis, Bob. 1993. Swimming in the Volcano. New York: Grove Press.

Shacochis, Bob. 1995. The Writing Life: A Collection of Essays and Interviews. New York: Random House.

Shacochis, Bob.. 2010. The Immaculate Invasion, 2nd ed. New York: Grove Press. Kindle edition.

Shacochis, Bob. 2013a. "Maximum Bob: An E-Mail Conversation with Bob Shacochis." Interview by Askold Melnyczuk. Los Angeles Review of Books September. https://lareviewofbooks. org/interview/maximum-bob-an-e-mail-conversation-with-bob-shacochis.

Shacochis, Bob. 2013b. The Woman Who Lost Her Soul. New York: Atlantic Monthly Press. Spiotta, Dana. 2013. Stone Arabia. New York: Scribner.

Thompson, Mark. 2010. "The U.S. Military in Haiti: A Compassionate Invasion." Time Magazine, January 16. http://content.time.com/time/specials/packages/article/0,28804,1953379_ 1953494_1954326,00.html. 
Turse, Nick. 2016. Tomorrow's Battlefield: US Proxy Wars and Secret Ops in Africa. Chicago, IL: Haymarket Books.

United Nations Development Program. 1994. Human Development Report 1994. New York: Oxford University Press.

US Department of Defense. 2010. Quadrennial Defense Review Report. Washington, DC: Department of Defense.

Walkowitz, Rebecca. 2015. Born Translated: The Contemporary Novel in the Age of World Literature. New York: Columbia University Press. Kindle Edition.

Wilcox, Lauren B. 2016. Bodies of Violence: Theorizing Embodied Subjects in International Relations. Oxford: Oxford University Press. 